\title{
Seroprevalence of transfusion transmissible infections (TTI), in first time blood donors in Abeokuta, Nigeria.
}

\author{
Babatunde Olanrewaju Motayo ${ }^{1,3}$, Adedayo Omotayo Faneye ${ }^{3}$, Usen Asuquo Udo $^{2}$, \\ Babatunde Adebiyi Olusola ${ }^{3}$, Isreal Ezeani ${ }^{\mathrm{I}, 2}$, Joseph Iruobe Ogiogwa ${ }^{1}$
}

1. Microbiology Unit, Pathology department, Federal Medical Centre, Abeokuta.

2. Hematology and Blood Transfusion Unit, Pathology department, Federal Medical

Centre, Abeokuta.

3. Department of Virology, College of Medicine, University of Ibadan.

\begin{abstract}
Background: Transfusion transmissible infections, such as HIV, HBV, HCV and syphilis are on the rise and pose a threat to blood safety.

Objective: To determine prevalence and demographic profiles of TTI's among first time blood donors in Abeokuta, Nigeria.

Methods: The study was conducted between February to November 2013; 130 first time blood donors were tested for the presence of HIV, HBsAg, HCV antibodies and Treponema palidium antibodies using EIA based rapid immunochromatographic kits. Data analysis was done using SPSS with a level of significance of $\mathrm{p}<0.05$.

Results: Prevalence rates to HIV, HBsAg, HCV antibody, were $6.2 \%(n=8), 10 \%(n=13)$ and $1.5 \%(n=2)$, there was $0 \%$ prevalence to Treponema palidium antibodies. Group specific prevalence rates revealed that educational status was associated with HBsAg positivity $(\mathrm{p}=0.028)$, donors with a history of previous blood transfusion was also statistically associated with HIV sero-reactivity $(\mathrm{p}=0.013)$.

Conclusions: High levels of HBsAg and HIV were observed, there is need to revise the donor testing algorithm in Nigeria in line with the prevalence of TTI's. We also advocate that a National surveillance system for TTI's be established through our National blood transfusion service (NBTS) program, a second serological test is also suggested to reduce the risk of occult HBV infection in Nigeria.
\end{abstract}

Key words: Prevalence rate, TTI's, Blood donors, Nigeria

DOI: http://dx.doi.org/10.4314/ahs.v15i1.3

\section{Introduction}

Blood transfusion remains one of the most important therapeutic options in life threatening disease conditions and also in sustaining life after severe blood loss 1. In Nigeria, demand for blood transfusion has been reported to be high as a result of frequent road traffic accidents, surgical and obstetric blood loss, as well as anemia from other sources ${ }^{2}$. Transfusion transmissible infections (TTI's), principally HIV $1 \& 2$, Hepatitis $\mathrm{B}$ and $\mathrm{C}$ viruses (HBV and HCV) as well as Syphilis, have continued to raise concerns about blood safety as

\footnotetext{
Corresponding author:

Babatunde Olanrewaju Motayo

Microbiology Unit,

Pathology department,

Federal Medical Centre,

P.M.B 3031 Sapon, Abeokuta.

E-mail-babatundemotayo@yahoo.com

Tel: +2348062632071
}

a result of the risk of infection. Sub-Saharan Africa remains one of the highest regions with these infections, with $68 \%$ of about 38 million HIV infected people residing in this, region ${ }^{3}$, while for almost 18 years the Central African region remained the highest HCV prevalent region worldwide 4 .

In Nigeria the main sources of blood for transfusion are commercial blood donors, replacement and voluntary blood donors ${ }^{1}$. Commercial blood donors are usually contracted to give blood to intending recipients for a negotiated fee. Replacement donors are mostly family members or close friends of the patient donating blood for use by the patient or inmost cases after transfusion under emergency cases. Voluntary donors are Nigerians who without any inducement donate blood to an unknown patient on companionate ground. Voluntary donors have been reported to be the safest group of donors because they tend to have better health seeking behavior than commercial blood donors ${ }^{2}$. The Nigerian government in trying to meet WHO set goals of $100 \%$ voluntary blood donation by $2020^{5,6}$, the $\mathrm{Na}$ tional Blood transfusion service (NBTS) was official- 
ly launched in the 6 geo-political zones in $2000^{1}$. Ever include, no previous history of blood donation, age of since then the Federal Ministry of health (FMoH) has 18 to 60 , and packed cell volume of 38\% and above. continued to review the NBTS policy and expand its All participants were counseled before consenting to activities. Currently there is a National Algorithm for partake after which they filled the consent and Donor donor screening for TTI's but despite all this effort, the information form. Tests that were done include blood risk of exposure to TTI's still remains,

There is urgent need to revise donor recruitment protocols as well as establish a blood safety surveillance system. The objective of this study was to determine the prevalence and demographic profile of HIV, HBV HCV and Syphilis among first time blood donors in Abeokuta, Nigeria.

\section{Material and Methods}

Study Area and study population: The study was conducted at Abeokuta capital city of Ogun state south west, Nigeria. It is located east of the Ogun river, coordinates are $302^{\circ} \mathrm{E} .7^{\circ} 9 \mathrm{~N}$. the city is $217 \mathrm{ft}$ above sea level and has a population of over 1 million inhabitants 9 . The study site is the Blood transfusion Unit of the Federal Medical centre Idi-aba, Abeokuta. It is the main referral Hospital in Ogun state serving the blood transfusion need of patients from around Ogun State and environs receiving treatment at the Hospital.

Study design: The study was a prospective analysis of blood transfusion transmissible infections among first time blood donors. It is part of the Blood transfusion unit blood procurement and transfusion surveillance program at Federal Medical center, Abeokuta, Nigeria. Study participants were drawn from both replacement donors and voluntary donors, consecutive sampling method was adopted. The study was done between February 2013 to November 2013. Recruitment criteria grouping, HIV1\&2 screening, HBsAg, anti- HCV, an Syphilis Ultra Rapid test (Qualitative detection of IoG and $\mathrm{IgM}$ antibodies to Treponema palidium antigens).

Serological testing: About $5 \mathrm{mls}$ of blood was drawn into anticoagulant bottle (EDTA) through venepunture. Testing was done for HIV $1 \& 2$ using a double paralle rapid kit Determine ${ }^{\circledR}$ (Abbot Labs Inc USA) and Sta Pak® Chembio. Test protocol and result interpretation was done according to the manufacturer instruction. HBsAg and HCV screening was done using immunochromatographic rapid kits by Diaspot $\mathbb{}($ (Djarkarta,Indonesia). Screening for Treponema palidium (Spyhilis) Antibodies was done Using ABON® Syphis Ultra Rapid Test strip (Abon Biopharm, Hangzhou Co, P.R. Chi-

Statistical analysis: Data analysis was conducted using the statistical software SPSS Vs 15 for Windows (SPSS Inc.Chicago IL). The chi square test was used to test for significance between variables, a value of $\mathrm{p}<0.05$ was

\section{Results:}

During the study period a total of 130 first time blood donors were screened age range 20 to 57 years, mean age $32 \pm 8$ yrs, median age 38. Majority of recruited donors were male $126(96.9 \%)$, other demographic varles such as marital status was almost evenly distributed (Table 1).

Table 1: Demographic distribution, among first time blood donors at FMC, Abeokuta, Nigeria 2013.

$\begin{array}{ll}\text { Variable } & \text { Frequency } \\ \text { Sex: Female } & \begin{array}{l}\text { N(\%) } \\ \text { Male }\end{array} \\ \text { Age: }<30 & 12.1) \\ 30-40 & 46(96.9) \\ 41 \text { And Above } & 66(50) \\ \text { Marital Status: Married } & 18(13.8) \\ \text { Single } & 72(55.4) \\ \text { Education Status: Secondary edu } & 58(44.6) \\ \text { Graduate } & 58(49.2) \\ \text { Illiterate } & 42(35) \\ \text { Missing } & 18(15) \\ \text { Previous receipt of } & 12(9.2) \\ \text { Blood Transfusion: Never } & 116(89.2) \\ \quad \text { At Least Once } & 14(10.8)\end{array}$

With regards to previous blood transfusions, $89.2 \%$ itive for $\mathrm{HBsAg}$ while $2(1.5 \%)$ were positive for anof recruited donors have never been transfused while ti-HCV. There was zero reactivity to Treponema $10.8 \%$ of recruited donors have been transfused at palidium antibodies among the tested participants; least once. With respect to individual tests carried out, there was no dual positivity recorded. $8(6.2 \%)$ were HIV positive donors, $13(10 \%)$ were pos-

\begin{tabular}{|c|c|c|c|c|c|c|}
\hline Variable & $\begin{array}{l}\text { HIV } \\
\text { Reactive }\end{array}$ & Non-React & P value $X^{2}$ & $\begin{array}{l}\text { HBsAg } \\
\text { Positive }\end{array}$ & Negative & P value $X^{2}$ \\
\hline $\begin{array}{l}\text { Male } \\
\text { Female }\end{array}$ & $\begin{array}{l}8(6.3 \%) \\
0(0 \%)\end{array}$ & $\begin{array}{l}118(93.7 \%) \\
4(100 \%)\end{array}$ & $\mathrm{P}>0.05$ & $\begin{array}{l}12(9.5 \%) \\
0(0 \%)\end{array}$ & $\begin{array}{l}114(90.5 \%) \\
4(100 \%)\end{array}$ & $P>0.05$ \\
\hline $\begin{array}{l}\text { Age } \\
<29 \\
30-40\end{array}$ & $\begin{array}{l}3(6.5 \%) \\
5(7.8 \%)\end{array}$ & $\begin{array}{l}43(93.5 \%) \\
59(92.2 \%)\end{array}$ & $P>0.05$ & $\begin{array}{l}2(4.3 \%) \\
4(12.1 \%)\end{array}$ & $\begin{array}{l}44(95.7 \%) \\
58(87.9 \%)\end{array}$ & $P>0,05$ \\
\hline $\begin{array}{l}\text { Marital } \\
\text { Status } \\
\text { Married }\end{array}$ & & $18(100 \%)$ & $P>0.05$ & $2(11.1 \%)$ & $16(88.9 \%)$ & $P>0.05$ \\
\hline $\begin{array}{l}\text { Single } \\
\text { Edu }\end{array}$ & $3(5.2 \%)$ & 65(94.8\%) & & $4(9.6 \%)$ & $\begin{array}{l}54(93.1 \%) \\
54(1 \%)\end{array}$ & \\
\hline $\begin{array}{l}\text { tatus } \\
\text { Secd sch } \\
\text { Graduate } \\
\text { Witerate }\end{array}$ & $\begin{array}{l}3(5.2 \%) \\
2(4.8 \%) \\
316.70\end{array}$ & $\begin{array}{l}55(94.8 \%) \\
40(95.2 \%) \\
1583.3 \%\end{array}$ & $\mathrm{P}>0.05$ & $\begin{array}{l}4(6.9 \%) \\
4(9.5 \%) \\
4(22.2 \%)\end{array}$ & $\begin{array}{l}54(93.1 \%) \\
38(90.5 \%) \\
14(9780)\end{array}$ & $P>0.05$ \\
\hline $\begin{array}{l}\text { Prev BT } \\
\text { Never }\end{array}$ & $6(5.1 \%)$ & $112(94.9 \%)$ & $\mathrm{P}=0.013^{*}$ & $10(8.6 \%)$ & $106(91.4 \%)$ & $P>0.05$ \\
\hline & $4(33.3 \%)$ & $8(66.7 \%)$ & & $2(14.3 \%)$ & $12(85.7 \%)$ & \\
\hline
\end{tabular}

Table 2 shows the various seroprevalence rates of in- variables did not show any statistically significant assodividual Transfusion transmissible infectious markers, ciation with seropositivity for any of the analyzed TTI HIV and HBsAg in relation to various categorical var- markers $\mathrm{p}>0.05$. Previous blood transfusion and HIV iables. Age range 30-40 recorded the highest preva- seropositivity, showed significant association, $\mathrm{p}=0.013$, lence $7.8 \%$ for HIV and $12.1 \%$ for HBsAg. Prevalence among first time blood donors, in FMC, Abeokuta. was higher among married than single participants. There was zero prevalence rate recorded for Syphilis The illiterate group recorded the highest prevalence antibodies (Treponema palladium), therefore no entry for both HIV and HBsAg seropositivity. All analyzed was recorded for anti-Syphilis antibody rate in our results as shown below.

Table 3

\begin{tabular}{|c|c|c|c|}
\hline Variable & $\begin{array}{l}\text { HCV Ab } \\
\text { Positive }\end{array}$ & Negative & P value $X^{2}$ \\
\hline Males & $2(1.6 \%)$ & $124(98.4 \%)$ & $\mathrm{P}>0.05$ \\
\hline $\begin{array}{l}\text { Females } \\
\text { Age }\end{array}$ & $0(0 \%)$ & 4(10010) & $D=005$ \\
\hline $\begin{array}{l}<29 \\
30-40 \\
>40 \\
\text { Marital }\end{array}$ & $\begin{array}{l}0(0 \%) \\
2(3 \%) \\
0(0 \%)\end{array}$ & $\begin{array}{l}46(100 \%) \\
64(97 \%) \\
18(100 \%)\end{array}$ & $P>0.05$ \\
\hline $\begin{array}{l}\text { Status } \\
\text { Married } \\
\text { Single }\end{array}$ & $\begin{array}{l}2(2.8 \%) \\
0(0 \%)\end{array}$ & $\begin{array}{l}70(97.2 \%) \\
58(100 \%)\end{array}$ & $\mathrm{P}>0.05$ \\
\hline $\begin{array}{l}\text { Edu Status } \\
\text { Secd sch } \\
\text { Graduate } \\
\text { Illiterate }\end{array}$ & $\begin{array}{l}0(0 \%) \\
0(0 \%) \\
2(11.1 \%)\end{array}$ & $\begin{array}{l}58(100 \%) \\
42(100 \%) \\
16(88.9 \%)\end{array}$ & $\mathrm{P}=0.028^{*}$ \\
\hline $\begin{array}{l}\text { Prev BT } \\
\text { Never } \\
\geq 1\end{array}$ & $\begin{array}{l}2(1.7 \%) \\
0(0 \%)\end{array}$ & $\begin{array}{l}114(98.3 \%) \\
14(100 \%)\end{array}$ & $P>0.05$ \\
\hline
\end{tabular}

Key: * = Significant value, Secd sch $=$ secondary education, Prev BT $=$ Previous receip 
Results in table 3 show the distribution of analyzed in Abeokuta (Ogun SACA 2014, unpublished data).It is variables in relation to prevalence of $\mathrm{HCV}$ antibodies also higher than the estimated national HIV prevalence among first time blood donors in Abeokuta. A similar rate put at about $4 \% \%^{2}$. Our report of $6.2 \%$ is lowe trend with HIV prevalence was observed in relation to than that of a recent study done in the same study site, category based HCV antibody prevalence. Educational which recorded $11.7 \%$ among hospital attendees ${ }^{10}$. It status was statistically associated with HIV prevalence, is also lower than that of a similar study done at Benin, only 2 of male donors were positive for HCV antibody. South-south, Nigeria which reported $7.2 \%$ prevalence Our report of $6.2 \%$ is however relatively high considering the fact that blood donors represent the healthy population group in any community. This points to the fact that HIV is still being actively transmitted among the most productive age bracket in our community. An overali $\mathrm{HBs} \mathrm{Ag}$ prevalence rate of $10 \%$ was recorded in our cuirent study (Figure 1)

Fig 1: Prevalence of serological markers for TTIs, HIV, HBsAg and HCV antibody among first time blood donors in FMC, Abeokuta.

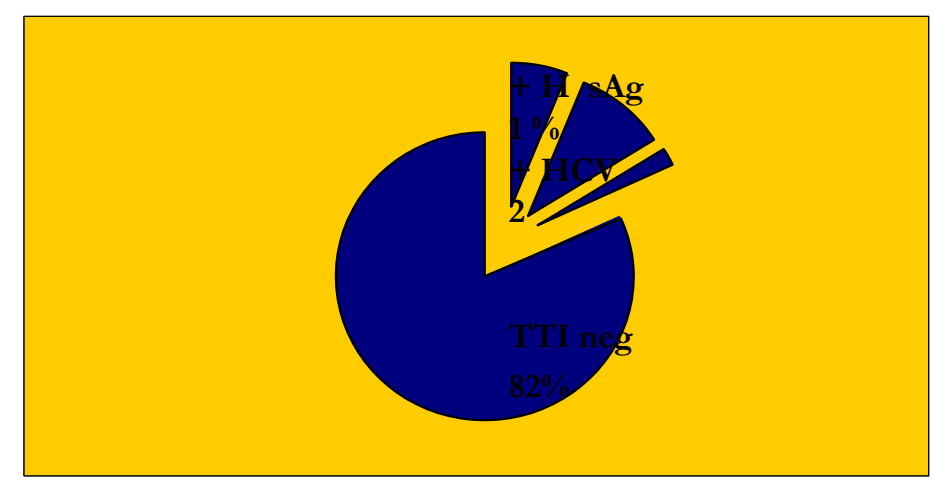

this is much higher than a similar study done at Lagos, which recorded $4.7 \% \%^{2}$ our results were much higher than a report of a similar study done at Yola, Nigeria $2.4 \%{ }^{11}$. Some previous reports were higher than ours for instance, a study done at Ibadan Nigeria by Fashola et al ${ }^{12}$ reported a prevalence rate of $13.2 \%$ another study done in the South-south region of Nigeria reported $10.6 \%{ }^{13}$, a prevalence rate of $8.3 \%$ in Tanzanian donors ${ }^{14}$. In Another study in Burkina Faso, HBV was the most prevalent TTI $(13.4 \%)$ of donors screened ${ }^{15}$. Other similar studies from other parts of sub-Saharan Africa have given similar high prevalence of HBV among blood donors for instance in South Sudan, $6.25 \% \mathrm{HBV}$ prevalence was reported ${ }^{16}$. In Eritrea, data from their National blood transfusion service is also in agreement with our current report ${ }^{17}$. The report of our study, reaffirms endemicity of HBV infection in sub-saharan, African communities ${ }^{8}$. Prevalence rate of anti-HCV antibodies among our study participants stood at $1.5 \%(\mathrm{n}=2)$, this is in accordance with previ-

ous reports of low seroprevalence of $\mathrm{HCV}$ in variou parts of Nigeria, $0.2 \%(2), 2.4 \%{ }^{11}$. Figure 1 shows the overall distribution of TTI serological markers, approximated to the nearest whole number, from fig 1 , about $82 \%$ of first time donors tested negative to all the TTI's There was no reactivity to Treponema palidium antibodies, among our study participants, the low rates of sero- reactivity to Treponema palidium antibodies has been previously reported among pregnant women in Abeokuta ${ }^{18}$. The low prevalence can be attributed to increased awareness against STI and availability and af fordability of effective antibiotics (Nwadike Personal communication). Similar trend as our current study has also been reported from countries with higher prevalence of HBV, such as, India 19,20 and Chin $^{21}$. There was no dual positivity among the tested donors.

Results from analysis of category based prevalence rates to individual TTI serological markers, revealed that only male gender recorded positive results, with $6.3 \%$ prevalence for HIV, 9.5\% HBsAg prevalence and 1.4\% $\mathrm{HCV}$, there was no significant association of any of the TTI in relation to gender. Seroprevalence rates of TTI markers in relation to age range distribution revealed that age range 30-40, had the highest rate, with HIV recording $7.8 \%$, HBsAg $12.1 \%$ and HCV 3\%. An interesting finding was that age range 29 and below recorded a lesser prevalence for HIV and HCV antibodies than other age groups; this is an indication of success on the part of Government agencies and Non-governmental organizations in the fight against new HIV infections. This is encouraging as previous studies have indicated that the adolescent age group is the driving force of new HIV infections in Nigeria ${ }^{22,23}$. Prevalence of TTI markers in relation to marital status was not statistically significant $(p>0.05)$, for all the tested TTI markers, although married donors recorded a higher prevalence for HIV, HBsAg and HCV antibody. This is an indication that more effort needs to be channeled toward family oriented prevention strategies for blood borne infections, as well as increase advocacy toward women empowerment on reproductive health issues. Results of T'TI prevalence rate according to educational status shows a statically significant association between HCV antibody prevalence and educational status $(\mathrm{P}=0.028)$. Illiterate donors recorded the highest prevalence of $11.1 \%$ for HCV, $16.7 \%$ for HIV and $26.5 \%$ for $\mathrm{HBsAg}$

Our result is in accordance to a recent study done in the same study location that reported significant association of $\mathrm{HBs} A g$ positivity with educational status ${ }^{8}$. This finding has been attributed to better health promotion practices and health seeking behavior amongst the educated ${ }^{8}$. Data generated also showed that previous history of blood transfusion among intending donors was statistically associated with HIV antibody positivity $(\mathrm{P}=0.013)$. This is expected as unsafe blood transfusion remains one of the major routes of HIV transmission in Nigeria ${ }^{24}$. A limitation to our study was our inability to consistently identify voluntary first time blood donors among our study group, this is however regretted. Based on our current finding we suggest a revision of donor screening test algorithm based on the currently observed prevalence. More research investigating actual National prevalence is however required.

\section{Conclusion}

From our current study, HBV recorded the highes prevalence rate among blood donors, followed by HIV and HCV, with Treponema palidium (Syphilis) record- ng zero prevalence. This reaffirms the endemicity of infections in Nigeria. HIV prevalence remains on the high side and new HIV transmission seems to continue, despite increased effort toward zero transmission rates as advocated by $\mathrm{WHO}^{25}$.

We recommend that a more efficient and robust testing algorithm be developed, with the most prevalent TTI, HBV, leading the series of test, followed by HIV, HCV and lastly Syphilis. The algorithm should be in such a manner as to exclude each infection according to their general prevalence. This will reduce cost of testing, turn around time and improve efficiency in a resource challenged setting such as ours. We also advocate that a National surveillance program against TTI be set up through the National Blood transfusion service (NBTS). The resultant data generated would be useful in updating policy regulation on donor testing in Nigeria. We also suggest the inclusion of a second serological test to exclude occult HBV infection. This can be either anti-HBc or HBeAg along side HBsAg test, to reduce the risk of accidental $\mathrm{HBV}$ infection in $\mathrm{HBs} A g$ egative blood donors, a possibility that has been previously reported in Nigeria ${ }^{26,7}$

\section{Conflict of Interes}

There are no conflicts of interests declared with regards to this research work.

\section{Acknowledgements}

The authors will like to acknowledge the efforts of the members of staff of the Blood

transfusion unit at Federal Medical Center, Abeokuta as well as the Hospital Management. We also acknowledge the effort of Mr. Femi Oluwasesi towards the success of this work.

\section{References}

1. Nwogoh B, Ikpowem O.D., Isoa E.M. Donor procurement and risk of transfusion transmissible viral infections in a tertiary health facility in South-south Nigeria. Nig Med J. Vol 52, no 3 pp 227-230, 2011

2. Salihu I. Policies, processes and procedures to ensure safe blood for transfusion. The Medical Laboratory Scientist. Vol 34. no 1\&2. pp 6-12, 2013.

3. WHO, Global HIV/AIDS response: Epidemic update and Health sector progress towards universal access, progress report 2011, WHO Geneva, Switzerland, 2011. 
4. Madhava V, Burgess C, and E. Drucker, Epidemiology of chronic Hepatitis C virus in Sub-saharan Africa, The Lancet vol 2, no. 5, pp. 293-302, 2002.

5. Blood safety and donation: fact sheet no. 279, 2008. Available from: http:/www.who.int/mediacentre/factsheets/es279/en/. 2008.

6. WHO: The Melbourne declaration on $100 \%$ voluntary non-remunerated donation of blood and blood components,2009. Available at: http:/www.who.int/entity/worldblooddonorday/Melbornedeclaration2009. doc.

7. Japhet M.O., Adesina O.A, Dombraye E and M.O Adewunmi, Hepatitis B core antibody among $\mathrm{HBsAg}$ negative blood donors in Nigeria., Virology J. vol 8, pp 513-518, 2011.

8. Motayo B.O, Akpa M.O, Ezeani I, Faneye A, Usen U, Onoja B, Seroprevalence rates of HBsAg and anti-HCV antibody among blood donors in a South-western, Nigerian city. Journal of Immunoassay and Immunochemistry. 2014: In press.

9. National Population Comission, National census sentinel, 2007.

10. Motayo B.O, Usen U, Folarin B.O, Okerentugba P.O, Innocent-Adiele H.C, and I.O Okonko, Detection and seroprevalence of HIV $1 \& 2$ antibodies in Abeokuta, Southwest, Nigeria, International Journal of Virology and Molecular biology, vol 1., no. 2 pp 18-22, 2012.

11. Olokoba A.B, Salawu F.K, Danburam A, Desalu O.O, Olokoba L.B et. al, Viral Hepatitides in voluntary blood donors in Yola, Nigeria, European Journal of Scientific Research, vol 31, no. 3, pp 329-334, 2009.

12. Fashola F.A, Kotila T.R and J.O Akinyemi, Trends in transfusion transmissible viral infections from 20012009 in Ibadan, Nigeria, Intervirology, vol 51, no. 6, pp 427-431, 2009.

13. Esumeh F.I, Ugbomioko D, and J.O Isibor, Seroprevalence of HIV and HBsAg in central hospital Benin city, Nigeria, J Med Lab Sci, vol 12, no. 2, pp 52-55, 2003.

14. Muktar H.M, Suleman A.M, and M Jones, Safety of blood transfusion: prevalence of HBsAg in blood donors in Zaria, Northern, Nigeria, Nigerian Journal of Surgical Research, vol 7, no. 3\&4, pp 290-292, 2005.

15. Nagalo BM., Bisseye C., Sanou M., Kienou K., Nebie YK et al, Seroprevalence and incidence of transmission tranmissible infectious diseases among blood donors from regional blood transfusion centers in Burkina Faso, West Africa. Trop Med Int Health. Vol 17, no 2 pp 247-253.
16. Abou M.A., Eltahir Y.M., Ali A.S, Seroprevalence of HBV and HCV among blood donors in Nyala, South Dar Fur, Sudan. Virol J. 23.6: 146: doi: 10.1186/1743422X-6-146.

17. Fessehayle N., Naik D., Fessehaye'T., Transfussion transmited infections-a retrospective analysis from the National blood transfusion service, Eritrea. Pan Afr Med J. 9. 40. PMID. PMC3215562.

18. Ogiogwa I.J, Akingbade O.A, Aboderin B.W, Okerentugba P.O et. al, Prevalence of Treponema palladium in serum of pregnant women in Abeokuta, Ngeria, Nature and Science, vol 10, no. 6, pp 91-94. 2012.

19. Kamarkar P.R., Shrivastava P., RayT.G.,Seroprevalence of tranusion transmisible infections at a blood bank of a Medical College of Kolkota. Indian J Public Health. 58 (1): 61-64. 2014.

20. Meena M., Jindal T., Hazarika A., Prevalence of HBV and HCV among blood donors at a tertiary care Hospital in India: a five year study. Transfusion Vol 55 no 1 pp 198-202.

21. Ji Z.H., Li C.Y., Lu Y.G., Cao W., Chen Z.Y., et al, The prevalence and trends of transfusion transmissible infectious pathogens among first time blood donors in Xi'an, China between 1999 and 2009. Int J Infect Dis. Vol 17 no 4; e259-62. doi:10.1016/j.ijid.2012.10.006.

22. Motayo B.O, Okonko I.O, Uche L.N, Onoja B.A and C.H Obiogbolu, The seroprevalence of HIV among patients attending the Special treatment clinic at University college hospital, Ibadan, Nigeria, Nig J Microbiol, vol 23, no. 1, pp 1904-1910, 2009.

23. Sule W.F, Enemunor S.C, Adewumi M.O, and O.C Attah, Traditional crop farmers in Kogi east, Nigeria elucidate elevated HIV and AIDS prevalence during a five year study period, Afr J Microbiol Res, vol 3, no. 4, pp 128-132, 2009.

24. Olaleye O.D, Tekena O.H, Odiabo G.N, The Virology and dynamics of the Epidemic: In AIDS in Nigeria: A nation on the threshold, Edited by: Adeyi O, Kanki P.J, Odutolou O, Idoko J, Harvard center for population and development studies, Cambridge, MA 02138 USA. pp 37-66, 2006.

25. World Health Organisation, Status of blood safety in the WHO Africa region: Report of the 2004 surrveyWHO regional office for Africa. Brasaville, WHO, 2007.

26. Ola S.O., Otegbayo J.A., Odiabo G.N., Olaleye O.D., Olubuyide I.O., Summerton C.B., Bamgboye E.A. Occult HBV infection among a cohort of Nigerian adults. J Infect Dev Ctries. vol 3, no.6 pp 442-6 2009. 